\title{
Javanese of Tegal: an Ecological Evidence
}

\author{
Mualimin Mualimin ${ }^{1, *}$, Marsono Marsono ${ }^{2}$, and Suhandano Suhandano ${ }^{2}$ \\ ${ }^{1}$ Linguistics Department, Faculty of Humanities, Diponegoro University, Semarang - Indonesia \\ ${ }^{2}$ Faculty of Cultural Science, Gadjah Mada University, Yogyakarta - Indonesia
}

\begin{abstract}
The relationship between language and environment has been a hot topic for decades. This study aims at finding out how the Javanese of Tegal dialect is used in poems written by the local poets of Tegal. The research uses Eco linguistics as well as dialect theories. The data are collected through library and interview methods. The results show that the authors of Poems in Javanese of Tegal make use of the local dialect in expressing their thoughts. The use of local dialect indicates by the use of local Javanese vocabulary and also the way the words are pronounced. The findings shows that the authors' choice of the dialect is closely interrelated with the environment where they live.
\end{abstract}

Keyword: Javanese of Tegal; ecolinguistics evidence, poem in Tegal dialect.

\section{Introduction}

The use of a language is bound to the culture in which the language exists. The existence of the Tegal dialect is also related to the belief of the community living in an environment where the dialect is spoken. The study concerning the relationship between language and its environment is called ecolinguistics which has been widespread since the early 1990s [1-3]. The study of the form of language used members of regional, ethnic or social group is also called dialect [4]. Poem as a mean of conveying messages is a kind of genre used by the author to express their thought. As a literary genre, a poem has its own features that make it different from other literary genres. That some features of the literary features are the use of connotative and stylish language [5]. Connotative means that the language used in literary work does not have actual meaning or not denotative meanings as it is used in scientific texts. Moreover, the language of literary work is also stylish which means that the language used is more aesthetic. Accordingly, sometimes the language used by a poet can be much different from the language used by others because of the aesthetic element. Because of aesthetic reasons, some of the literary works have more imaginative content than the factual one, and therefore, to understand literary works also requires a deep understanding of other fields such as the environment of the writer. The vocabulary of a language reflects both the physical and social environment of its speakers [6]. The problem of this paper is how the relationship between the environment and the Tegal dialect.

\section{Methods}

There are five poems written by five different writers in Tegal dialect which are used as the resouce for this study. The poems are entitled "Srengenge Wuda Bral" by S. Harries [7], "Sabanyu Tunggal Putu" by D. E. Santoso [8], "Aja Takon maring Enyong” by H. Utomo [9], "Potret Besem Tegal 98" by L. Setiawan [10], and "Dzikir Reformasi by A. Lahire" [11]. The poems which are collected in one volume named Potret Reformasi dalam Puisi Tegalan edited by Kepanjen[ 12] were chosen ramdomly in that those are the first poem written by each writer in the collection. The data, in the form of lexicon, are taken from five poems which are then analyzed descriptively by studying their forms and also their function in the lines of the poems considering the context of their use. The lexicons found then are classified based on their function by looking at the same words as they use in the local Javanese dictionary entitled Kamus Bahasa Jawa Tegal - Indonesia [13].

\section{Finding and Discussion}

Based on the analysis using the dictionary [13], there are 41 lexicons of Tegal Dialect found in five poems. The distribution of the lexicons and their classification can be seen in Fig. 1 below.

* Corresponding author: mualiminischaqfibundip@gmail.com 


\section{The use of Tegal Dialect Lexicons}

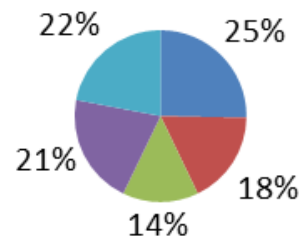

\section{Noun/ Pronoun \\ Adjective} $14 \%$

Fig. 1. The use of Tegal dialect Lexicon.

Based on Fig. 1 above there are 41 lexicons used in five poems which are found in Kamus Bahasa Jawa Tegal - Indonesia. The lexicons are unique and not found in the standard Javanese dictionary [14]. It means that those words are uniquely found in the Tegal dialect and not found elsewhere. In other words, the use of the words is bound to the speakers' background or environment where they live. In terms of content words, the number of lexical words found in those five poems is almost the same. The number of Nous and pronouns is 11 out of 41 words, verbs and adjectives are equal in number, 10 words, whereas the number of adverbs is less than that of nouns, verbs, and adjectives. The least number is a particle which is always the least in any language.

When the data are observed carefully the use of Noun and Pronoun can be seen in the following table.

Table 1 The noun and pronoun in five poems

\begin{tabular}{|c|c|c|c|}
\hline \multicolumn{4}{|c|}{ The Noun / Pronoun \& their pronunciation } \\
\hline Javanese of Tegal & $\begin{array}{c}\text { Std. } \\
\text { Javanese }\end{array}$ & $\mathbf{F}$ & $\%$ \\
\hline $\begin{array}{l}\text { Gemiyen [gəmiyen] } \\
\text { 'In the old days' }\end{array}$ & Biyen & 3 & 13 \\
\hline $\begin{array}{l}\text { Rika [rika] } \\
\text { 'you' }\end{array}$ & Panjenengan & 1 & 4 \\
\hline $\begin{array}{l}\text { Mbesiki [mbəsiki] } \\
\text { 'tomorrow' }\end{array}$ & Sesuk & 1 & 4 \\
\hline $\begin{array}{l}\text { Kowen [kowən] } \\
\text { 'you' }\end{array}$ & Kowe & 1 & 4 \\
\hline $\begin{array}{l}\text { Enyong [əјо)] } \\
\text { 'I' }\end{array}$ & $A k u$ & 8 & 34 \\
\hline $\begin{array}{l}\text { Tukang ogan [tukan ogan] } \\
\text { 'Fortune teller with cards' }\end{array}$ & Tukang ramal & 1 & 4 \\
\hline $\begin{array}{l}\text { Agor [agor] } \\
\text { 'husky sound due to } \\
\text { sorethroat' }\end{array}$ & Serak & 1 & 4 \\
\hline $\begin{array}{l}\text { Kiye [kiye] } \\
\text { 'This' }\end{array}$ & Iki & 6 & 26 \\
\hline $\begin{array}{l}\text { Nyana [nana] } \\
\text { 'imagine' }\end{array}$ & Sangka & 1 & 4 \\
\hline & Total & 23 & 100 \\
\hline
\end{tabular}

There are three words which are used more than once, those are the word gemiyen [gəmiyen] ' in the old days', enyong [onyony] 'I', and kiye [kiye]'this'. The word gemiyen [gəmiyen] has the same meaning as biyen [biyen] in standard Javanese. The word enyong [əлор] in standard Javanese has the same meaning with aku [aku] or kula [kul॰], and kiye [kiye] with the word iki.

The other noun words are only used once. The corresponding words in standard Javanese for those words are sampeyan or panjenengan for rika [rika], esuk for mbesiki [mbəsiki], kowe for kowen [kowən], tukang ramal for tukang ogan [tukan ogan], serak for agor [agor], iki for kiye[kiye], and sangka for nyana [nana].

The use of those nouns and pronouns shows that the writers use the words which are familiar to them to express their thoughts. Based on an interview with them it is known that they chose the words because they felt easy and comfortable to do so. They think that they are confident using the words in their local language, Javanese of Tegal dialect.

In addition, the distribution of adjectives in a dialect of Tegal can be seen in Table 2 below.

Table 2. The Distribution of adjectives

\begin{tabular}{|c|c|c|c|}
\hline \multicolumn{4}{|c|}{ The Adjectives \& their pronunciation } \\
\hline Javanese of Tegal & $\begin{array}{c}\text { Std. } \\
\text { Javanese }\end{array}$ & $\mathbf{F}$ & $\%$ \\
\hline $\begin{array}{l}\text { wuda bral [wuda bral] } \\
\text { 'naked' }\end{array}$ & Wuda blejet & 1 & 6 \\
\hline $\begin{array}{l}\text { Kabongan [kaboyan] } \\
\text { 'Overwhelmed' }\end{array}$ & onggrongan & 1 & 6 \\
\hline $\begin{array}{l}\text { Langka [layka] / laka [laka] } \\
\text { 'lack' }\end{array}$ & Ora ana & 3 & 19 \\
\hline $\begin{array}{l}\text { Kolu }[\text { kolu }] \\
\text { 'bear' }\end{array}$ & Tega & 1 & 6 \\
\hline $\begin{array}{l}\text { Maning [manin] } \\
\text { 'again' }\end{array}$ & Meneh & 2 & 13 \\
\hline $\begin{array}{l}\text { Bureng [burəy] } \\
\text { 'Unclear' }\end{array}$ & Blereng & 1 & 6 \\
\hline $\begin{array}{l}\text { Jor [jor] } \\
\text { 'Let (it) go' }\end{array}$ & Umbar & 1 & 6 \\
\hline $\begin{array}{l}\text { emong [əmon] } \\
\text { 'Reluctant' }\end{array}$ & Emoh & 1 & 6 \\
\hline $\begin{array}{l}\text { Umeb [uməb] } \\
\text { 'boiling' }\end{array}$ & Umep & 2 & 13 \\
\hline $\begin{array}{l}\text { Angas [anas] } \\
\text { 'violent' }\end{array}$ & Kasar & 1 & 6 \\
\hline $\begin{array}{l}\text { Gobal-gabel [gobal-gabel] } \\
\text { 'bad' }\end{array}$ & Ala & 1 & 6 \\
\hline $\begin{array}{l}\text { Mbleret }[\text { mblərət }] \\
\text { 'weakening' }\end{array}$ & Surem & 1 & 6 \\
\hline & Total & 16 & 100 \\
\hline
\end{tabular}

Table 2 shows how the adjectives are used in the poems written by the writers. There are three words used more than once, those are langka [lanka] or laka [laka] 'lack', maning [manin], and umeb [uməb] repectively. The other adjectives are used once only in those five poems. The use of those local lexicons of Tegal dialect indicates the writers not only use nouns or pronouns in the local dialect but also used adjectives. The use of adjectives in writing poems means that the writers feel comfortable and pleased using the words. Poems as 
kinds of literary works are intended by the writers to express their feeling about what is happening around their lives as mentioned by [3, 14].

Apart from adjectives, here is the use of Verbs in those five poems written in Javanese of Tegal dialect.

Table 3. The use of Verbs

\begin{tabular}{|c|c|c|c|}
\hline \multicolumn{4}{|c|}{ The Verbs \& their pronunciation } \\
\hline Javanese of Tegal & Std. Javanese & $\mathbf{F}$ & $\%$ \\
\hline Maen [maen] & Ethok-ethok & 1 & 8 \\
\hline Ngempra [yəmpra] & ngawur & 1 & 8 \\
\hline Teka [təka] & teka [təko] & 1 & 8 \\
\hline $\begin{array}{l}\text { Metek [mətek] / Mbadhek } \\
\text { [mbadek] }\end{array}$ & bedhek & 2 & 16 \\
\hline Metongsot [metoysot] & $\begin{array}{l}\text { Lungguh } \\
\text { anteng }\end{array}$ & 1 & 8 \\
\hline $\begin{array}{l}\text { Ditombreng tombreng } \\
\text { [ditombren-tombren] }\end{array}$ & diisinke & 2 & 16 \\
\hline Digedhag [digəḍag] & dioyak & 1 & 8 \\
\hline Keplathok [kəplatok] & dibalang & 1 & 8 \\
\hline Kejet-kejet [kədzət-kədzət] & klejetan & 1 & 8 \\
\hline $\begin{array}{l}\text { mlethuk-mlethuk [mləțuk- } \\
\text { mləțuk] 'erupt' }\end{array}$ & $\begin{array}{l}\text { Mbledhug- } \\
\text { mbledug }\end{array}$ & 1 & 8 \\
\hline Nyrowok [nrowok] & nimbrung & 1 & 8 \\
\hline & Total & 13 & 100 \\
\hline
\end{tabular}

There are 13 lexicons of the Tegal dialect used in the poems. The use of the lexicons indicates that the writers also used verbs that exist in the dialect. This also shows the influence of the environment to the language where the writers live [4].

The use of adverbs found in the poems can be seen fro the following table.

Table 4. The use of Adverbs

\begin{tabular}{|l|l|c|c|}
\hline \multicolumn{4}{|c|}{ The Adverbs \& their pronunciation } \\
\hline \multicolumn{1}{|c|}{ Javanese of Tegal } & Std. Javanese & F & \% \\
\hline Ndeyan [ndeyan] & Menawa & 1 & 5 \\
\hline Ngenjleg [nendleg] & Gagah & 1 & 5 \\
\hline Bae [bae] & Wae & 2 & 11 \\
\hline Gemrujug [gəmrudjug] & Gemrojog & 1 & 5 \\
\hline Monia [monia] & Sanajan & 2 & 11 \\
\hline Kecocos [kətotfos] & Tunceb & 1 & 5 \\
\hline Mbules [mbuləs] & Mbulek & 1 & 5 \\
\hline Pan [pan] & Arep & 3 & 16 \\
\hline $\begin{array}{l}\text { Poma rong poma } \\
\text { [poma ron poma] }\end{array}$ & Aja lali & 6 & 32 \\
\hline Dongkah [dojkah] & Suwek & 1 & 5 \\
\hline & Total & 19 & 100 \\
\hline
\end{tabular}

By looking at the table above, it can be seen that there are many adverbs found in the dialect which are used in the poems. This also indicates that the writers use certain terms found in the dialect which shows their interrelation with the environment.

Apart from content words, certain typical particles are found in the dialect of Tegal. The following table shows the use of particles in the poems.
Table 5. The use of Particles

\begin{tabular}{|l|l|c|c|}
\hline \multicolumn{4}{|c|}{ The Particles \& their pronunciation } \\
\hline Javanese of Tegal & Std. Javanese & F & \% \\
\hline Maring [marin] & meng & 7 & 35 \\
\hline $\begin{array}{l}\text { Daning [danin] / } \\
\text { ganing [ganin] }\end{array}$ & kok & 2 & 10 \\
\hline Nang [nay] & ning & 9 & 45 \\
\hline Ka [ka] & loh & 1 & 5 \\
\hline Tuli [tuli] & terus & 1 & 5 \\
\hline & Total & 20 & 100 \\
\hline
\end{tabular}

From Table 5 above, there are five particles found in the poems written in the dialect of Tegal. Those five particles may not be found in standard Javanese. Similar words may have different use in a different dialect.

From the discussion, it can be summarized that the existence of the Tegal dialect is closely related to the language phenomena in the region. Accordingly, the use of a language is influenced by the environment where the language exists.

\section{Conclusion}

From the explanation, it can be concluded that there is a close relationship between the environment and the language used where a community lives. The use of certain lexicons in the forms of either lexical or structural words in a certain dialect proves that the use of a language is interrelated with the ecology where the language exists.

This finding may be beneficial for the social life of the people living in the region in the 4.0 industrial era in which people are always involved in social engineering in the coming years.

\section{Acknowledgement}

The writer would like to extend his gratitude to his supervisors while studying at UGM, and also to the Dean of Faculty of Humanities, Diponegoro University who has supported the writer to conduct a small research dealing with the topic under the research scheme of the year 2019 .

\section{References}

1. A. Fill, P. Muhlhausler, The Ecolinguistics Reader: Language, Ecology and Environment, London: Continuum (2001)

2. F.M. Hult, Ecology and Multilingual Education, C.A. Chapelle (ed.( The Encyclopedia of Applied Linguistics, Blackwell publishing (2013)

3. R.D. Busser, R.J. LaPolla, Language Structure and Environment, Amsterdam: John Benjamins Publishing Co. (2015)

4. Z. Salzmann, J.M. Stanlaw, N. Adachi, Language, Culture, and Society, Philadelphia: Westview Press, (2012)

5. R.D. Pradopo, Ragam Bahasa Sastra, Humaniora IV, Faculty of Literature UGM (1977) 
6. E. Sapir, Language and Environment, AA 14, 226242 (1912)

7. S. Harries, Srengenge Wuda Bral, Potret Reformasi dalam Bahasa Tegalan, Tegal: Jurnal Tegal Tegal (1998)

8. D.E. Santoso, Sabanyu Tunggal Putu, Potret Reformasi dalam Bahasa Tegalan, Tegal: Jurnal Tegal Tegal (1998)

9. H. Utomo, Aja Takon maring Enyong, Potret Reformasi dalam Bahasa Tegalan, Tegal: Jurnal Tegal Tegal (1998)

10. L. Setiawan, Potret Besem Tegal 98, Potret Reformasi dalam Bahasa Tegalan, Tegal: Jurnal Tegal Tegal (1998)

11. A. Lahire, Dzikir Reformasi, Potret Reformasi dalam Bahasa Tegalan, Tegal: Jurnal Tegal Tegal (1998)

12. E. Kepanjen, Potret Reformasi dalam Bahasa Tegalan Tegal: Jurnal Tegal Tegal (1998)

13. M.H. Utomo, et al., Kamus Bahasa Jawa TegalIndonesia, Semarang: Balai Bahasa Iawa Tengah (2017)

14. S. Nardiati, Suwadji, Sukardi, Pardi, E. Suwatno, Kamus Bahasa Jawa-Bahasa Indonesia, Jakarta: PPPB, Depdikbud, (1993) 